\title{
Identification of the Wheat Curl Mite as the Vector of the High Plains Virus of Corn and Wheat
}

\author{
Dallas L. Seifers, Associate Professor, Kansas State University, Agricultural Research Center-Hays, Hays 67601- \\ 9228; Tom L. Harvey, Professor, Department of Entomology, Kansas State University, Manhattan 66506; T. J. \\ Martin, Professor, Kansas State University, Agricultural Research Center-Hays; and Stanley G. Jensen, USDA- \\ ARS, University of Nebraska, Lincoln 68583-0722
}

\begin{abstract}
Seifers, D. L., Harvey, T. L., Martin, T. J., and Jensen, S. G. 1997. Identification of the wheat curl mite as the vector of the High Plains virus of corn and wheat. Plant Dis. 81:1161-1166.

Wheat with virus-like symptoms (extracts containing a 33-kDa protein in sodium dodecyl sulfate-polyacrylamide gel electrophoresis, negative in enzyme-linked immunosorbent assay to wheat streak mosaic virus, and not infectious in a backassay to other wheat) reacted positively to antiserum made against a protein purified from symptomatic corn infected with the High Plains virus (HPV), indicating a serological relationship between the corn and wheat pathogens. The wheat curl mite (WCM, Aceria tosichella Keifer) was identified as the vector of the virus and caused persistent infection of barley (Hordeum vulgare L.) and wheat (Triticum aestivum L.) in greenhouse experiments. The HPV was recovered in the field from naturally infected wheat where the number of HPV-infected plants decreased with increasing distance from the WCM source in volunteer wheat.
\end{abstract}

In September of 1993, volunteer "Newton" wheat (Triticum aestivum L.) with mosaic symptoms was harvested from a field $5 \mathrm{~km}$ south of Hays, Kansas. The wheat was used as a source of the wheat curl mite (WCM; Aceria tosichella Keifer) for transfer in the greenhouse to KS91H184 wheat, an experimental line that is resistant to wheat streak mosaic virus (WSMV; 13). In October 1993, a few KS91H184 plants were observed with severe mosaic symptoms. Extracts from one of these plants was negative in an enzyme-linked immunosorbent assay (ELISA) against WSMV antiserum and was not infectious to wheat in mechanical inoculation tests. Extracts also had a 33$\mathrm{kDa}$ protein band when analyzed by sodium dodecyl sulfate-polyacrylamide gel electrophoresis (SDS-PAGE) that was not present in WSMV-infected wheat or healthy wheat. The plant was negative in ELISA against antisera of Agropyron mosaic virus, brome mosaic virus, maize dwarf mosaic virus (MDMV), sugarcane mosaic virus strain MDMV-B, and maize chlorotic mottle virus. An additional wheat

Corresponding author: D. L. Seifers

E-mail: dseifers@oznet.ksu.edu

Contribution 97-306-J from the Kansas Agricultural Experiment Station. Research was supported in part by a grant from the Kansas Wheat Commission.

Accepted for publication 30 June 1997.

Publication no. D-1997-0818-01R

(C) 1997 The American Phytopathological Society plant (DL2213) from Stanton County, Kansas (supplied by Bob Bowden, Kansas State University) was tested and showed the same reactions as the KS91H184 wheat.

In the same year, corn infected by an unidentified virus was found in Texas, Kansas, Idaho, and Colorado. A 32-kDa protein band observed in SDS-PAGE was associated with this virus, and an antiserum was prepared against this protein (4). The symptomatic KS91H184 wheat from Hays and the symptomatic wheat from Stanton County, Kansas gave positive reactions in ELISA when tested against this antiserum.

We report here results (i) establishing a serological relationship between the corn and wheat pathogens presently known as the High Plains virus (HPV), (ii) identifying the WCM as the vector of HPV, (iii) using barley as a host to acquire pure culture of HPV, (iv) demonstrating WCMinduced symptoms similar to those of HPV, and (v) demonstrating the development and distribution of HPV over time in naturally infected wheat.

\section{MATERIALS AND METHODS}

Sources of antisera and cross-absorption and testing of HPV antiserum. Antiserum against the HPV was prepared as described by Jensen et al (4). The HPV antiserum was cross-absorbed as follows: 8 $\mathrm{g}$ of healthy $\mathrm{N} 28 \mathrm{Ht}$ corn and $8 \mathrm{~g}$ of WSMV-infected "Tomahawk" wheat were ground in $20 \mathrm{ml}$ of ELISA blocking buffer

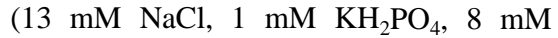
$\mathrm{Na}_{2} \mathrm{HPO}_{4}, 2.6 \mathrm{mM}$ KCL, $0.5 \mathrm{ml}$ Tween 20, $20.0 \mathrm{~g}$ polyvinylpyrrolidone [molecular weight 40,000], $2.0 \mathrm{~g}$ ovalbumin, $0.2 \mathrm{~g}$ $\mathrm{NaN}_{3}, \mathrm{pH} 7.4$, distilled water to 1 liter).
The extract was filtered through cheesecloth and then centrifuged at $5^{\circ} \mathrm{C}$ for 15 $\min$ at $48,400 \times g$. The volume of supernatant was measured, and 1/100 volume of whole antiserum was added (whole antiserum was used because of the small volume of antiserum available). The diluted antiserum was incubated in a water bath at $37^{\circ} \mathrm{C}$ for $1 \mathrm{~h}$ and centrifuged at $5^{\circ} \mathrm{C}$ for $15 \mathrm{~min}$ at $27,200 \times g$. Antiserum treated in this way was considered as a 1:100 $\mathrm{vol} / \mathrm{vol}$ stock solution. The whole non-cross-absorbed antiserum diluted 42 times in phosphate buffered saline had an absorbance at 280 $\mathrm{nm}$ of 1.7 , giving an estimate at $53 \mathrm{mg} / \mathrm{ml}$ of total protein for the undiluted stock (3).

Antisera to Agropyron mosaic virus and wheat streak mosaic virus were prepared as previously described (10), as were antisera for maize dwarf mosaic virus and sugarcane mosaic virus strain MDMV-B (11). Brome mosaic virus antiserum (PVAS 178) and maize chlorotic mottle antiserum (PVAS 262) were obtained from the American Type Culture collection (Rockville, MD).

Indirect ELISA. The procedure used was as previously described (12). Leaf tissue in all studies was ground at a 1:30 $\mathrm{wt} / \mathrm{vol}$ dilution in coating buffer (2), and antiserum to the HPV was used at a 1:50,000 dilution made from the 1:100 cross-absorbed stock in ELISA blocking buffer described above. The antirabbit antibody:alkaline phosphatase conjugate (1:3,000, vol/vol; Sigma Chemical Co., St. Louis) and WSMV antibodies (1:800, $\mathrm{vol} / \mathrm{vol}$ from a $1 \mathrm{mg} / \mathrm{ml}$ stock solution) were diluted using ELISA blocking buffer All samples, antibody solutions, and substrate solutions were used at a $200 \mu \mathrm{l}$ vol. Substrate ( $p$-nitrophenyl phosphate, 0.714 $\mathrm{mg} / \mathrm{ml}$ ) in substrate buffer (2) was added, the plates were incubated at room temperature, and the absorbance (405 nm) was measured after 30 min (Titertek Mulitskan microelisa plate reader, Flow Laboratories, Inc.).

Infectivity assays. Seven days after planting, Tomahawk wheat and "Westford" barley (Hordeum vulgare L.) plants were inoculated manually with $1: 10 \mathrm{wt} / \mathrm{vol} \mathrm{ex}-$ tracts as previously described (11). Inoculated plants were maintained in a greenhouse at temperatures of 18 to $30^{\circ} \mathrm{C}$.

Maintenance of plants and infestation by WCM. Eggs of WCM were transferred 
to wheat to establish a WSMV-free WCM colony. These wheat plants were maintained in a growth chamber (Warren/Sherer Model CEL39-15) with $12 \mathrm{~h}$ of fluorescent light (approximately $500 \mu \mathrm{E} \cdot \mathrm{s}^{-1} \cdot \mathrm{m}^{-2}$, at plant height). The WCMs were increased by laying WCM-infested wheat (negative in ELISA for HPV and WSMV) onto the plants. As the plants dried, the WCMs moved from the drying leaves to the new plants (2-leaf stage), and as the infested plants dried, the WCMs moved from the drying leaves to the new plants. The infested plants were tested individually by ELISA, at 28 to 35 days following infestation, for the presence of HPV or WSMV. This system was replaced by one in which the wheat was planted into "plant cells" (2.4- by $16.5-\mathrm{cm}$ plastic planting cones; Stuewe \& Sons, Corvallis, OR) and immediately covered by vinyl capped, tubular nitrocellulose, 25 - by $305-\mathrm{mm}$ plastic tubes (Sinclair \& Rush Co. St. Louis) that had 8 or 10 12-mm-diameter holes, which were covered with nylon mesh with 16- $\mu$ m-diameter openings (3-35/16×x; H.R. Williams Mill Supply Co., Kansas City, MO) for ventilation. This nylon mesh provided a barrier against passage of WCMs (Tom Harvey, unpublished) in our tests, because it has an opening smaller than the reported size ( 33 by 80 to 47 by $150 \mu$ ) for the firstinstar WCM nymphs (14). The WCM culture (using the plastic cage system) was maintained by transferring pieces of WCM-infested wheat leaf tissue (previously testing negative in ELISA against HPV and WSMV antisera) to leaves of the Tomahawk wheat. A slit was made with a needle at the base of the first leaf, and the infested leaf piece was inserted into the hole. As the leaf piece dried, the WCMs crawled onto the living leaf and infested the plant. Plants used as a source of WCMs for HPV acquisition were assayed by ELISA for HPV and WSMV prior to use. The original WCM source was a collection from Ellis County, Kansas. The WCM used in these studies at Kansas and Nebraska was identified as Aceria tosi- chella by J. W. Amrine (West Virginia University).

To acquire the HPV, leaf pieces from WCM-infested wheat (negative in ELISA for HPV and WSMV) were attached by a hair clip to HPV-source plants, and the WCMs were allowed a 24-h acquisition period. The WCMs were transferred manually (using a hair glued to a wooden dowel) from the HPV-infected source plant to the appropriate host. The WCM source plants and test plants were covered with plastic cages (as described above), both before and after infestation.

At Nebraska, a virus-transmitting colony of WCMs was established from wheat leaves showing virus symptoms, which were obtained from C. M. Rush (Texas A\&M University, Amarillo). The leaf pieces were examined microscopically and determined to be infested with A. tosichella, but not with any other insects or mites. In a growth chamber maintained at $22^{\circ} \mathrm{C}$ with $16 \mathrm{~h}$ of light, infested wheat leaves were placed individually on pots of "Center" wheat at the third-leaf stage of development. In less than a week, chlorotic spots were appearing on the leaves of several plants. In about 2 weeks, leaf rolling was apparent on some leaves and microscopic observation showed that a WCM population was developing. ELISA tests of symptomatic plants indicated the presence of both HPV and WSMV, and that these viruses were being transmitted by the WCMs. Mechanical transmission from these plants to wheat and maize recovered WSMV, but never HPV. These results were confirmed by ELISA testing for both viruses.

Using this method of WCM propagation and virus transmission, we observed that wheat seedlings became so severely diseased they died within a month of infestation. This was before the WCM population reached its maximum level. In subsequent work, initial infestation was delayed until the wheat seedlings were in the five- to six-leaf stage.

To transfer HPV and WSMV to maize or wheat, plants to be inoculated were placed in alternate positions with the WCM-infested wheat, and the leaves of the infested wheat were placed in contact with the recipient plants. After 3 to 5 days, the recipient plants were removed from the growth chamber, and the WCMs were killed by spraying with Pentac (dienochlor; Sandoz, Inc., Hanover, NJ). This procedure usually resulted in rapid and uniform expression of virus symptoms.

Minipurification, SDS-PAGE, estimation of relative molecular masses, and Western blotting of proteins. Previously described procedures were used for extraction, minipurification of HPV protein $(6,7)$, calculation of relative molecular masses by densitometry (12), and SDS-PAGE (5).

Electrophoretic analyses were repeated at least twice with extracts from different plants. Healthy plant tissue was treated identically for all determinations.

Plant extractions, separations by SDSPAGE, and transfer of proteins onto nitrocellulose membranes were done exactly as described previously (12). The immunoblotting was done using alkaline phosphatase conjugated to antirabbit goat antibody (1).

Field sampling. Samples were taken from a field of "Victory" wheat planted on 18 September 1994 just north of the field of volunteer wheat from which HPV was first identified. Forty wheat plants were selected randomly and marked in each of five east-west strips (100 m long) located $1,8,16,32$, and $36 \mathrm{~m}$ from the volunteer wheat. The newest leaf of each plant was tested by ELISA (as described above) against antiserum to HPV and WSMV on 15 April, 21 April, 6 May, and 20 May 1995.

\section{RESULTS AND DISCUSSION}

Serological relationship of corn and wheat pathogens. Antiserum to the HPV 32-kDa protein reacted with WSMV and with healthy wheat and corn prior to crossabsorbing (Table 1). The reactions with healthy wheat and corn were reduced greatly following cross-absorption; how-

Table 1. Enzyme-linked immunosorbent assay values from a 1:50 (wt/vol) dilution of wheat infected by an unknown pathogen (DL 2213), wheat streak mosaic virus (WSMV)-infected wheat, and healthy corn and wheat when tested against cross-absorbed and non-cross-absorbed antiserum ${ }^{\mathrm{a}}$ made to the High Plains virus isolated from corn

\begin{tabular}{|c|c|c|c|c|c|c|c|c|}
\hline \multirow[b]{3}{*}{ Antiserum dilution } & \multicolumn{8}{|c|}{ Antiserum treatment } \\
\hline & \multicolumn{4}{|c|}{ Cross-absorbed } & \multicolumn{4}{|c|}{ Non-cross-absorbed } \\
\hline & DL 2213 & WSMV Sidney & Healthy corn & Healthy wheat & DL 2213 & WSMV Sidney & Healthy corn & Healthy wheat \\
\hline $1: 100$ & 0.298 & 0.449 & 0.199 & 0.189 & 2.000 & 2.000 & 2.000 & 0.921 \\
\hline $1: 200$ & 1.126 & 1.063 & 0.079 & 0.067 & 2.000 & 1.779 & 1.869 & 0.654 \\
\hline $1: 400$ & 1.419 & 0.812 & 0.056 & 0.036 & 1.839 & 1.269 & 1.438 & 0.476 \\
\hline $1: 800$ & 1.319 & 0.419 & 0.035 & 0.026 & 1.601 & 0.852 & 0.917 & 0.274 \\
\hline $1: 1,600$ & 1.199 & 0.208 & 0.029 & 0.007 & 1.394 & 0.486 & 0.514 & 0.168 \\
\hline $1: 3,200$ & 0.940 & 0.093 & 0.024 & 0.006 & 1.156 & 0.259 & 0.316 & 0.091 \\
\hline $1: 6,400$ & 0.822 & 0.047 & 0.000 & 0.000 & 0.910 & 0.130 & 0.161 & 0.048 \\
\hline $1: 12,800$ & 0.680 & 0.031 & 0.003 & 0.000 & 0.720 & 0.063 & 0.085 & 0.018 \\
\hline $1: 25,600$ & 0.505 & 0.016 & 0.003 & 0.000 & 0.521 & 0.032 & 0.049 & 0.008 \\
\hline $1: 51,200$ & 0.353 & 0.009 & 0.005 & 0.000 & 0.351 & 0.019 & 0.020 & 0.004 \\
\hline $1: 102,400$ & 0.244 & 0.012 & 0.004 & 0.000 & 0.229 & 0.016 & 0.013 & 0.000 \\
\hline
\end{tabular}

a Antiserum made as described (4). 
ever, some reactivity to WSMV was still present. Cross-absorbed HPV antiserum was not visually positive for WSMV at the 1:6,400 (0.047) dilution or at a 1:25,600 (0.049) dilution for non-cross-absorbed antiserum. The cross-absorbed antiserum reacted to the DL2213 wheat sample, indicating that it contained a pathogen serologically related to the pathogen infecting corn. Tissue from the HPV-infected KS91H184 wheat plant, a KS91H184 wheat plant singly infected by WSMV (by WCM transfer), and a healthy KS91H184 wheat were minipurified, and the proteins separated by SDS-PAGE and then Western blotted. Only one band of approximately $33 \mathrm{kDa}$ was observed from the HPV-positive wheat, whereas many bands were observed from WSMV-infected wheat and healthy KS91H184 wheat in the SDSPAGE counterpart gel (Fig. 1A). A protein band running just slightly ahead of the band from the HPV-positive wheat was observed for the other two treatments. When the extract was tested in Western blotting, using a 1:25,600 dilution of crossabsorbed antiserum, only the band (arrow) in the HPV lane reacted (Fig. 1B). This indicated that the viruses infecting KS91H184 wheat and corn were serologically related, and that the cross-absorbed antiserum was specific for the HPV in ELISA and for the $32-\mathrm{kDa}$ protein by Western blotting. The slight difference between the relative mass reported for HPV from corn (4) and these results reflect minor variations in experimental procedures between the two laboratories.

Vectoring of HPV. Because the original Hays wheat samples (testing positive in ELISA to HPV antiserum) were infested by WCMs, it was logical to assume that the WCM might be the vector of the HPV. Therefore, WCMs (10 to 15 WCMs/plant; WCMs from original source field) were transferred from the HPV-positive KS91H184 wheat in the greenhouse to this KS91H184 wheat (plants previously tested negative in ELISA against both HPV and WSMV). In transfer 1, 11 of 60 plants tested positive in ELISA for HPV (HPV ELISA values of 0.111 to 0.281 and healthy control value of 0.009 ), 10 of these also tested positive for WSMV, and the remaining 49 plants were symptomless and negative in ELISA. WCMs were obtained from the HPV-positive KS91H184 wheat from transfer 1 and transferred (5 WCMs/plant) to wheat for transfer 2. In this experiment, 17 of 80 plants were positive for HPV (HPV ELISA values of 0.108 to 0.557 and healthy control value of $0.018), 15$ of which also tested positive for WSMV; the remaining 63 plants were negative in ELISA. A third transfer was done by transferring WCMs (3 WCMs/plant) from the 2 plants considered infected only by HPV in transfer 2 to KS91H184 wheat. Of these plants, 11 of 20 tested positive for HPV (HPV ELISA values of 0.281 to 1.020 and healthy control value of 0.014$), 6$ tested positive for both pathogens, 9 plants tested negative in ELISA for either HPV and WSMV, and none tested positive for WSMV alone. In these transfers, the positive threshold for WSMV infection was a value equal to or greater than twice the value of the healthy control against WSMV antiserum. All 5 plants testing positive for only HPV in transfer 3 were tested for infectivity by mechanical transmission in a backassay to wheat, and none were infective. This demonstrated that no WSMV was present and that HPV was not transmitted mechanically.

Although these 5 plants were not infective, they may have had low levels of WSMV not detectable in infectivity assays, because $\mathrm{KS} 91 \mathrm{H} 184$ is temperature-sensitive and loses resistance to WSMV at $25^{\circ} \mathrm{C}$ (13). The plants in transfers 1 and 2 , considered as infected by HPV only, were not tested by the mechanical infectivity assay. The data from these three experiments supported the hypothesis that the WCM is a vector of the HPV. This places HPV in the group of viruses vectored by the WCM, including wheat streak mosaic virus (14), wheat spot mosaic virus (15), and the wheat spot chlorosis pathogen $(8,9)$; the latter are not mechanically transmitted. KS91H184 wheat infested by pathogenfree WCMs raised on healthy wheat did not react in ELISA to antisera to HPV or WSMV, nor were the plants infectious in backassay from transfer 3 .

Influence of barley on titer of HPV. We observed that Westford barley infected by both HPV and WSMV had some plants with very low ELISA values for WSMV, and these often were associated with higher ELISA values for HPV (Table 2). Therefore, we used Westford barley to determine if a culture of the HPV free of WSMV could be obtained by single WCM transfers.

In experiment 1,80 plants were infested with WCM obtained from wheat doubly infected with HPV and WSMV. Twenty plants became infected with both HPV and WSMV, 18 were positive only to HPV, and 2 were infected with WSMV only, based on an ELISA value of twice that of the equivalent healthy control for WSMV. In experiment 2, WCMs were obtained from barley plants in experiment 1 that had tested positive to only HPV, and transferred to 20 healthy barley plants. Three plants became infected with both HPV and WSMV, 8 with HPV only, and none with WSMV only. The 8 plants considered infected by HPV only were tested by mechanical backassay, and 3 were infectious for WSMV on wheat. The 3 WSMV-infected plants had ELISA values against WSMV antiserum that were 1.9 to 2.2 times higher than that of the healthy control, indicating that twice the healthy control value for WSMV was too high.
The remaining 5 uninfected plants had values ranging from 1.0 to 1.4 times higher than the value for healthy barley. Therefore, the threshold value was dropped to

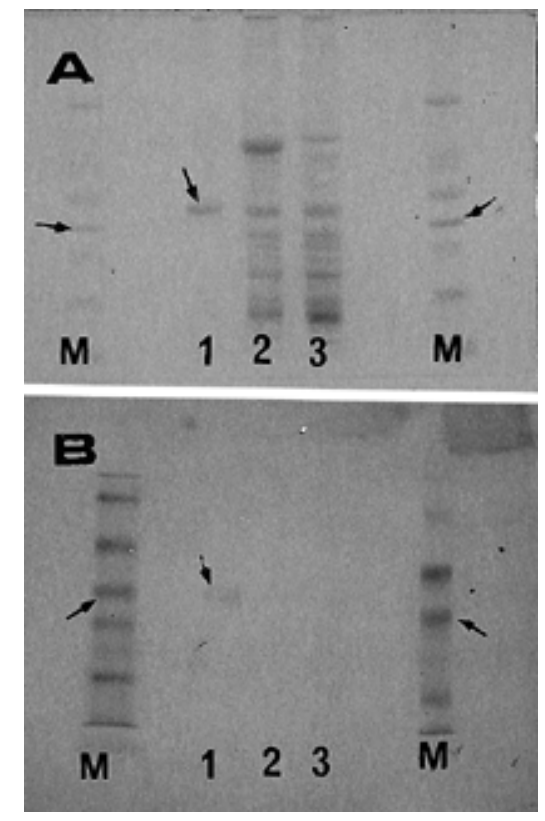

Fig. 1. High Plains virus (HPV) protein concentrated from wheat by minipurification, separated by sodium dodecyl sulfate-polyacrylamide gel electrophoresis (SDS-PAGE), stained with Coomassie blue $(0.125 \%$ Coomassie blue R-250, $50 \%$ methanol, and $10 \%$ acetic acid) (A), probed with antibodies to HPV (1:25,000 dilution) and antirabbit goat antibody:alkaline phosphatase conjugate (1:3,000 dilution/Bio-Rad 170-6518) in a Western blot (B). (A) SDS-PAGE gel counterpart to that used for Western blot. Lane 1, KS91H184 wheat positive in enzyme-linked immunosorbent assay (ELISA) for HPV; lane 2, KS91H184 wheat positive in ELISA for wheat streak mosaic virus; lane 3, healthy KS91H184 wheat; lanes $\mathrm{M}$, molecular mass standards: (A) bovine serum albumin $(66 \mathrm{kDa})$, egg albumin $(45$ $\mathrm{kDa}$ ), glyceraldehyde-3-P-dehydrogenase (36 $\mathrm{kDa})$, bovine carbonic anhydrase $(29 \mathrm{kDa})$ (arrow), bovine pancreas trypsinogen $(24 \mathrm{kDa})$, soybean trypsin inhibitor $(20 \mathrm{kDa})$, and bovine milk a-lactalbumin $(14.2 \mathrm{kDa})$. Arrow marks a band of approximately $33 \mathrm{kDa}$ found in wheat infected by HPV. (B) Western blot of SDS-PAGE. Treatments in lanes are as described for (A). Arrow marks band equivalent to that marked in (A). Lane $\mathrm{M}$ on left side of gel contains prestained molecular mass markers; pre-stained markers (Bio-Rad 161-0318): myosin (205 kDa), B-galactosidase $(116.5 \mathrm{kDa})$, bovine serum albumin $(72 \mathrm{kDa})$, carbonic anhydrase $(32.5 \mathrm{kDa})$, soybean trypsin inhibitor $(27.5 \mathrm{kDa})$, lysozyme $(18.1 \mathrm{kDa})$, and aprotinin $(7.1 \mathrm{kDa})$. The arrow denotes position of 32.5 carbonic anhydrase. Arrow in lane $\mathrm{M}$ on right side of gel denotes position of 31.3-kDa soybean trypsin inhibitor of the Kaleidoscope prestained markers (Bio-Rad 161-0324): myosin (217 kDa), beta-galactosidase $(130 \mathrm{kDa})$, bovine serum albumin $(72 \mathrm{kDa})$, carbonic anhydrase $(41.8 \mathrm{kDa})$, soybean trypsin inhibitor (31.3 kDa), lysozyme (18.1 kDa), and aprotinin $(7.1 \mathrm{kDa})$. Electrophoresis was in a $10 \%$ gel, $0.75 \mathrm{~mm}$ thick. Duration of electrophoresis was $37 \mathrm{~min}$ (Mini-Protean II cell for SDS-PAGE and MiniTrans-Blot Cell for Western blotting; Bio-Rad, Richmond, CA), with volts and $\mathrm{mA}$ set at 200 and 120 , respectively. 
1.4 times that of the healthy control when selecting HPV source plants from experiment 2 for experiment 3 .

In experiment 3 , pathogen-free WCMs raised from eggs on healthy wheat were given a 24-h acquisition period on a single barley plant from experiment 2 testing positive to HPV in ELISA and with an ELISA value for WSMV of 1.4 times higher than that of the equivalent healthy control. These WCMs then were transferred singly to healthy barley plants. After 3 weeks, 8 barley plants tested positive in ELISA for HPV and were not infectious in backassays (1:10, wt/vol, dilution) to wheat. Control barley plants infested with pathogen-free WCMs were negative in ELISA for both HPV and WSMV and not infectious for WSMV in backassay. These 8 barley plants from experiment 3 then were used as the source of HPV for maintenance of the HPV culture using pathogen-free WCMs. Twice during subsequent WCM transfer of HPV (10-month period), WSMV was detected by ELISA in the HPV culture. The WSMV source may have been contaminated by viruliferous WCMs during transfers, or possibly a low level of WSMV existed in the culture that was not consistently detectable by infectivity assay. In each instance, barley positive for only HPV in ELISA and noninfectious for WSMV in backassay was selected, and the HPV culture started again from these plants. We also observed that the number of barley plants successfully infected by HPV using a single WCM diminished over time, so that eventually 10 or more WCMs had to be used to infest each plant to maintain the HPV isolate. The reasons for this are unknown; however, a similar decrease over time in transmission of the wheat spot chlorosis pathogen by a single WCM from $50 \%$ to less than $1 \%$ was reported by Nault and Styer (8).

WCM-induced symptoms. In some instances, Westford barley (infested using pathogen-free WCMs that had previously fed on HPV-infected tissue) was rated as symptomatic (spots and faint mosaic), but tested negative in ELISA against HPV and WSMV antisera. These plants often had WCMs infesting them. We analyzed symptomatic barley testing either negative or positive in ELISA for HPV by minipurification, SDS-PAGE, and Western blotting. Only the barley positive in ELISA for HPV had a 33-kDa band (arrow) present in SDSPAGE (Fig. 2A, lane 9), and also in the Western blot (Fig. 2B, lane 9). No band was present in the WSMV-infected barley (lane 10), in the symptomatic barley negative in ELISA but infested with WCMs acquired from HPV-infected barley (lanes 1 to 5), or from barley infested by pathogen-free wheat curl mites (lanes 6 and 7). Lane 8 is an extract from noninfested healthy barley. The tissue that was negative in ELISA was not infectious in backassays to wheat. Based on these results, we interpreted the symptoms resulted from WCM feeding. Such responses to WCM feeding have been reported previously in studies concerning WCM vectoring of wheat spot mosaic virus (15). Therefore, although symptom notes were taken, symptoms were not used as definitive criteria for demonstrating infection by HPV. Infection by HPV was demonstrated by using an ELISA value of 0.100 or greater and/or the presence of the 33-kDa band in SDSPAGE or Western blotting. The 0.100
ELISA value was chosen because the 33$\mathrm{kDa}$ band was always present when tissue with this level of reaction in ELISA was tested in minipurification and SDS-PAGE and Western blotting.

A threshold value equal to or 1.4 times greater than that of the equivalent healthy control was established to verify that a plant was not infected by WSMV, because in some experiments values between 1.5 and 2 times greater than that of the healthy control were infective in backassay.

Development and distribution of HPV in naturally infected wheat. When fieldgrown wheat (adjacent to the volunteer wheat from which the HPV isolate was obtained in the greenhouse) was tested for HPV, 11 of 112 symptomatic plants tested positive in ELISA for HPV during the four assay periods (Table 3). No plant tested positive for HPV at the first assay (15 April 1995).

However, at the second assay (21 April), 4 plants were positive for HPV; at the third assay (6 May), 10 plants were positive for HPV; and at the fourth assay (21 May), only 2 plants remained alive that were previously positive for HPV. Plant 17 tested positive for HPV at each sample but had very little live tissue remaining at the last sampling. Plant 31 had not tested positive previously and could have been infected later or could have contained a

Table 3. Distance in meters of Victory wheat from volunteer Newton wheat, assay number, and sample numbers of individual wheat plants (from $200^{\mathrm{a}}$ at each sampling) that tested positive ${ }^{\mathrm{b}}$ in enzymelinked immunosorbent assay (ELISA) against antiserum to the High Plains virus (HPV)

\begin{tabular}{lcrrr}
\hline Distance & Assay 1 & Assay 2 & \multicolumn{1}{c}{ Assay 3 } & Assay 4 \\
\hline 1 & 0 & $4,17,38$ & $4,5,12,15,17,37,38$ & 17,31 \\
8 & 0 & 46 & 46 & 0 \\
16 & 0 & 0 & 98 & 0 \\
32 & 0 & 0 & 101 & 0 \\
36 & 0 & 0 & 0 & 0 \\
\hline
\end{tabular}

${ }^{a}$ Eighty-eight plants of the 200 sampled and tested were symptomless and tested negative for HPV and wheat streak mosaic virus (WSMV) in ELISA at all sampling dates.

${ }^{b}$ All plants testing positive for HPV also tested positive against WSMV antiserum. Plants were considered positive for HPV when ELISA values were 0.100 or greater, and positive for WSMV when ELISA values were equivalent to or 1.4 times greater than the value of the healthy control.

Table 2. Enzyme-linked immunosorbent assay (ELISA) values from KS91H184 wheat and Westford barley plants, each infested with 5 wheat curl mites having previously fed on wheat positive in ELISA to the High Plains virus (HPV) and wheat streak mosaic virus (WSMV)

\begin{tabular}{|c|c|c|c|c|c|c|}
\hline \multirow[b]{2}{*}{ Plant infested } & \multicolumn{2}{|c|}{ Experiment 1} & \multicolumn{2}{|c|}{ Experiment 2} & \multicolumn{2}{|c|}{ Experiment 3} \\
\hline & HPV & WSMV & HPV & WSMV & HPV & WSMV \\
\hline Wheat & 0.268 & 0.672 & 0.043 & 0.253 & 0.242 & 0.208 \\
\hline Wheat & 0.143 & 0.686 & 0.220 & 0.222 & 0.364 & 0.325 \\
\hline Wheat & 0.375 & 0.982 & 0.058 & 0.149 & 0.311 & 0.297 \\
\hline Wheat & 0.131 & 0.675 & 0.392 & 0.215 & 0.057 & 0.350 \\
\hline Wheat & 0.147 & 0.978 & 0.042 & 0.245 & 0.069 & 0.266 \\
\hline Barley & 0.334 & 0.873 & 0.236 & 0.225 & 0.432 & 0.247 \\
\hline Barley & 0.914 & 0.802 & 0.320 & 0.237 & 0.412 & $0.159^{\mathrm{a}}$ \\
\hline Barley & 0.480 & $0.285^{\mathrm{a}}$ & 0.316 & 0.184 & 0.381 & 0.258 \\
\hline Barley & 1.066 & $0.290^{\mathrm{a}}$ & 0.192 & 0.147 & 0.502 & 0.317 \\
\hline Barley & 0.266 & 0.843 & 0.227 & $0.090^{\mathrm{a}}$ & 0.336 & 0.282 \\
\hline Healthy wheat & 0.014 & 0.263 & 0.012 & 0.076 & 0.031 & 0.121 \\
\hline Healthy barley & 0.011 & 0.254 & 0.007 & 0.081 & 0.003 & 0.083 \\
\hline HPV & 1.200 & 0.284 & 0.310 & 0.056 & 0.205 & 0.047 \\
\hline WSMV & 0.017 & 1.487 & 0.028 & 0.432 & 0.039 & 1.163 \\
\hline
\end{tabular}

a These plants positive in ELISA for HPV, and the WSMV ELISA value was not twice that of the healthy wheat control. 

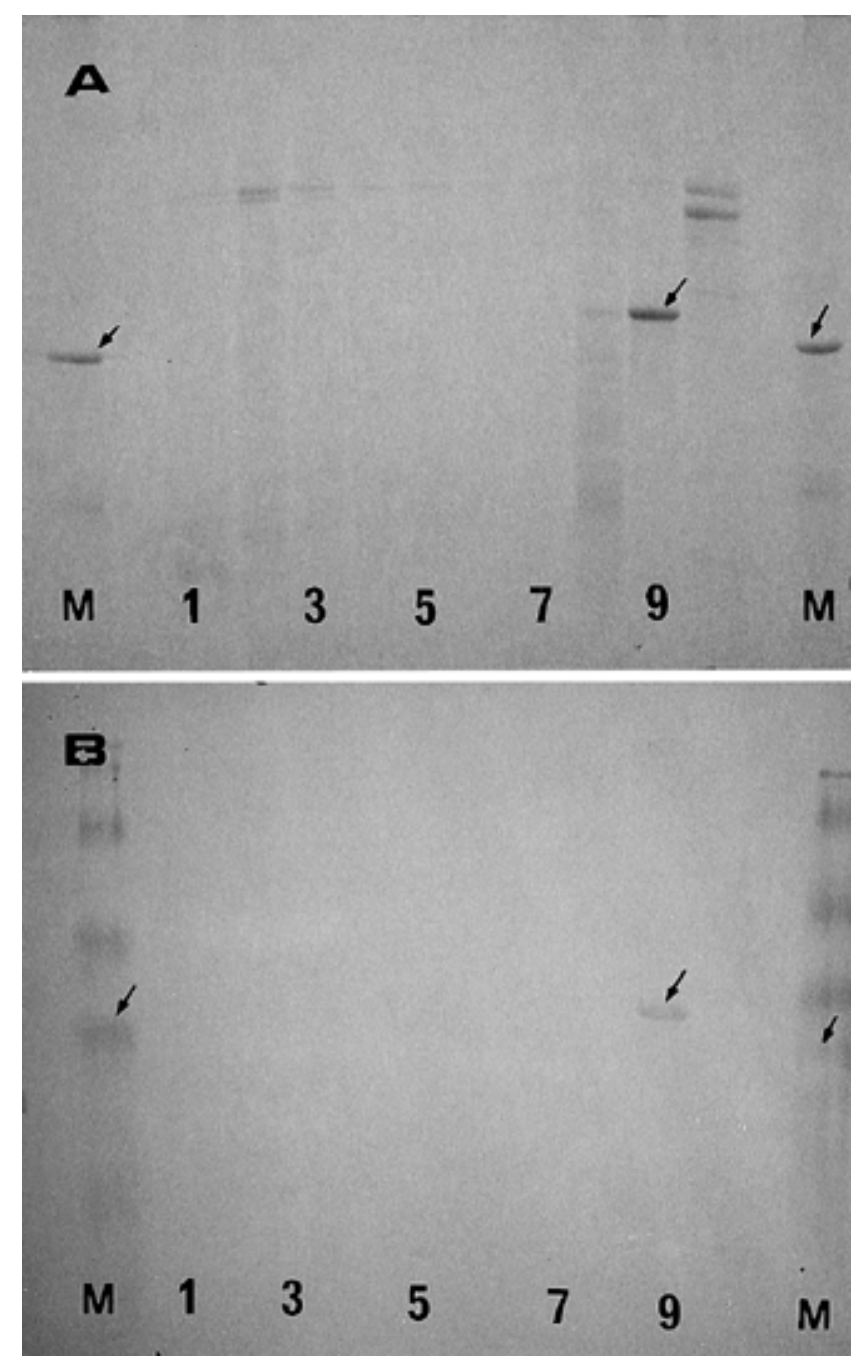

Fig. 2. High Plains virus (HPV) protein (arrow lane 9) concentrated from "Westford" barley by minipurification and separated by sodium dodecyl sulfate-polyacrylamide gel electrophoresis (SDSPAGE), stained with Coomassie blue (0.125\% Coomassie blue R-250, 50\% methanol, and $10 \%$ acetic acid) (A), and probed with antibodies to HPV (1:25,000 dilution) and antirabbit goat antibody:alkaline phosphatase conjugate (1:3,000 dilution/Bio-Rad 170-6518) in a Western blot (B). (A) SDS-PAGE gel counterpart to that used for Western blot. Lanes 1 to 5, symptomatic Westford negative in ELISA for HPV and wheat streak mosaic virus (WSMV); lanes 6 to 7, symptomatic Westford barley infested with pathogen-free wheat curl mites obtained from healthy wheat; lane 8, noninfested healthy barley; lane 9, HPV-infected Westford barley; lane 10, WSMV-infected Westford barley. Lane M, molecular mass markers as described for gel A of Figure 1A. Arrow marks position of 29$\mathrm{kDa}$ protein. (B) Western blot of gel loaded identically to counterpart gel (A). Arrow in lane 9 indicates equivalent band to that in (A) from symptomatic barley testing positive in ELISA to HPTV. Lane $\mathrm{M}$ on left side loaded with prestained markers as described for gel B of Figure 1. Arrow indicates position of $32.5-\mathrm{kDa}$ marker. Arrow in lane $\mathrm{M}$ on right side of gel denotes position of $31-\mathrm{kDa}$ marker for Kaleidoscope prestained markers as described for Figure 1B. Electrophoresis was in a 10\% gel, $0.75 \mathrm{~mm}$ thick. Duration of electrophoresis was $3 \mathrm{~h} 15 \mathrm{~min}$ (SE600 tank, Hoefer Scientific, Instruments, San Francisco) with volts and $\mathrm{mA}$ set at 400 and 30, respectively. Western blotting was done in a TE 50 Transphor unit (Hoefer Scientific, Instruments) at $100 \mathrm{~V}$ for $1 \mathrm{~h}$.

slowly replicating strain of HPV. The largest number of HPV-infected plants was located in the sampling strip closest to the volunteer wheat. All plants testing positive for HPV in ELISA also tested positive for WSMV. All 112 symptomatic plants tested positive for WSMV. The 88 symptomless plants tested negative in ELISA for both HPV and WSMV. The numbers of WSMVinfected plants at the 1-, 8-, 16-, 32-, and 36-m sample locations were 31, 24, 27, 19, and 11, respectively. This decline in numbers of HPV- and WSMV-infected plants
Symptomatic wheat (extracts containing a 33-kDa protein in SDS-PAGE, negative in ELISA to WSMV, and not infectious with WSMV when used to inoculate other wheat) is infected by a pathogen that is related serologically to or possibly is the same as the pathogen (HPV) infecting corn to which the antiserum used in this study was made. We have identified the WCM as the vector of HPV. Both pathogen-free WCMs raised from eggs and WCMs from source plants infected by both WSMV and HPV caused HPV infections of barley and wheat in the greenhouse. Transfer of HPV by single WCMs declined over time for unknown reasons, so that increased numbers of WCMs were necessary to maintain the HPV isolate. The HPV was not mechanically transmissible in any assay used during these experiments. Future work concerning this pathogen should include the effect of different WCM sources on its ability to vector HPV, determination of host range for the HPV, variability in HPV isolates for response to vectoring, host range, and responses to HPV isolates on selected corn and wheat lines.

\section{ACKNOWLEDGMENTS}

We wish to thank Jeff Ackerman for his excellent work and insights during these studies, and Bob Bowden for the sample of DL 2213 wheat.

\section{LITERATURE CITED}

1. Bollig, D. M., and Edelstein, S. J. 1991. Immunoblotting. Pages 181-208 in: Protein Methods. Wiley-Liss, New York.

2. Clark, M. F., and Adams, A. N. 1977. Characteristics of the microplate method of enzyme-linked immunosorbent assay for the detection of plant viruses. J. Gen. Virol 34:475-483.

3. Hurn, B. A. L., and Chantler, S. 1980. Production of reagent grade antibodies. Methods Enzymol. 70:125.

4. Jensen, S. G., Lane, L. C., and Seifers, D. L. 1996. A new disease of maize and wheat in the high plains. Plant Dis. 80:1387-1390.

5. Laemmli, U. K. 1970. Cleavage of structural proteins during the assembly of head of bacteriophage T4. Nature 227:680-685.

6. Lane, L. C. 1978. A simple method for stabilizing protein-sulfhydryl groups during SDSgel electrophoresis. Anal. Biochem. 86:655664.

7. Lane, L. C. 1986. Propagation and purification of RNA plant viruses. Methods Enzymol 118:687-696.

8. Nault, L. R., and Styer, W. E. 1970. Transmission of an eriophyid-borne wheat pathogen by Aceria tulipae. Phytopathology 60:16161618.

9. Nault, L. R., Styer, W. E., Gordon, D. T., Bradfute, O. E., Lafever, H. N., and Williams, L. E. 1970. An eriophyid-borne pathogen from Ohio and its relation to wheat spot mosaic virus. Plant Dis. Rep. 54:156-160.

10. Seifers, D. L. 1992. Partial characterization of a Colorado isolate of Agropyron mosaic virus. Plant Dis. 76:564-569.

11. Seifers, D. L., and Caceres, J. 1988. Titer variation in infected sorghum differing in resistance to maize dwarf mosaic virus strain-B. Phytopathology 78:208-212.

12. Seifers, D. L., Harvey, T. L., Kofoid, K D., and Stegmeier, W. D. 1996. Natural infection of pearl millet and sorghum by wheat streak mosaic virus in Kansas. Plant 
Dis. 80:179-185.

13. Seifers, D. L., Martin, T. J., Harvey, T. L., and Gill, B. S. 1995. Temperature sensitivity and efficacy of wheat streak mosaic virus resistance derived from Agropyron intermedium. Plant Dis. 79:1104-1106.
14. Slykhuis, J. T. 1955. Aceria tulipae Keifer (Acarina:Eriophyidae) in relation to the spread of wheat streak mosaic. Phytopathology 45:116-128.

15. Slykhuis, J. T. 1956. Wheat spot mosaic, caused by a mite-transmitted virus associated with wheat streak mosaic. Phytopathology 46:682-687.

16. Willis, W. G., 1981. The 1981 Wheat Streak Mosaic Epidemic in Kansas. Cooperative Extension Report, Kansas State University, Manhattan. 